\title{
Plantain Bananas PIF Seedlings Treatment with Liquid Extracts of Tithonia diversifolia Induces Resistance to Black Sigatoka Disease
}

\author{
Robinson Nembot Tatsegouock¹, Cécile Annie Ewané1,2*, Arouna Meshuneke1, \\ Thaddée Boudjeko ${ }^{1,2}$ \\ ${ }^{1}$ Laboratory of Phytoprotection and Plant Valorization, Biotechnology Center, University of Yaoundé 1, Messa-Yaoundé, \\ Cameroon \\ ${ }^{2}$ Department of Biochemistry, Faculty of Science, University of Yaoundé 1, Yaoundé, Cameroon \\ Email: ${ }^{*}$ cecile-annie.ewane@facsciences-uyl.cm
}

How to cite this paper: Tatsegouock, R.N., Ewané, C.A., Meshuneke, A. and Boudjeko, T. (2020) Plantain Bananas PIF Seedlings Treatment with Liquid Extracts of Tithonia diversifolia Induces Resistance to Black Sigatoka Disease. American Journal of Plant Sciences, 11, 653-671.

https://doi.org/10.4236/ajps.2020.115049

Received: April 12, 2020

Accepted: May 15, 2020

Published: May 18, 2020

Copyright $\odot 2020$ by author(s) and Scientific Research Publishing Inc. This work is licensed under the Creative Commons Attribution International License (CC BY 4.0).

http://creativecommons.org/licenses/by/4.0/

\begin{abstract}
Plantain bananas culture encounters the problems of seedlings quantity and quality unavailability. Black Sigatoka Disease (BSD) is one of the main pathological constraints of banana that can severely reduce the photosynthetic leaf area, leading to the losses of production of about $50 \%$ in banana plantation. The use of liquid extracts of Tithonia diversifolia could potentially induced the resistance of the PIF seedlings to BSD during the vegetative stages in the nursery. The aim of this work was to evaluate the effect of Tithonia diversifolia liquid extracts against the development of BSD on the PIF plantain bananas seedlings. The explants in the greenhouse and the seedlings in the shade were watered with liquid extracts of $T$. diversifolia during the process of PIF seedling production in sterile and non-sterile conditions. The treated seedlings show a more effective enhancement of seedlings quality parameters and also induce resistance against BSD. The vegetative stages parameters (the number of shoots, the diameter and the height of shoots, the foliar area, the length and weight roots) were improved in treated seedlings compared to controls ones. The treated seedlings showed maximum protection against BSD of up to $87 \%$ compared to controls. They also exhibited an increase in the accumulation of total proteins and total phenolics, as well as the activity of defense-related enzymes (peroxidase, polyphenol oxidase and glucanase). The treatment seems to acts as a vital stimulator and could therefore be a useful tool for small holder farmers favouring an eco-friendly agriculture using fewer synthetic inputs.
\end{abstract}

\section{Keywords}

Plantain Banana, PIF Seedlings, Tithonia diversifolia, Black Sigatoka Disease, 
Induced Resistance, Vital Stimulator

\section{Introduction}

Banana (Musa spp.) is one of the most important fruits and food crops in the world with annual production of more than $100 \mathrm{Mt}$ [1]. In the large family of Musaceae, there are many subgroups of hybrid triploid varieties: $\mathrm{AAB}$ and $\mathrm{ABB}$ (cooking banana) which result from the hybridization between wild ancestors AA (Musa acuminata) and BB (Musa balbisiana). Plantain bananas undergo various transformations and are used in the gastronomy due to their high energy value and rich mineral as well as dietary fiber and vitamin content. They, therefore, play a vital role in contributing to food security for the people in Central and West Africa.

In Cameroon, the production of plantain bananas is estimated at 3.94 million tons per year and it is ranked $3^{\text {rd }}$ in the world and the first in the Central African Economic and Monetary Community (CEMAC) zone [1]. The Plantain bananas consumption is very high, therefore mobilizing more than 650,000 actors in the sector and they are at the heart of trade in the sub-Central African regions [2]. The per capita consumption of plantain bananas is 159 and $126 \mathrm{~kg} /$ person/year respectively in Gabon and Cameroon [3]. The production is managed by smallholder farmers in small scale which is characterized by low productivity and thus less creation of new plantations. Such low productivity is due to growing and emergent pests and diseases present in banana's phytobiome.

Plantain bananas suckers come from old plantations and are commonly extracted to produce seedlings for plants renewals in the traditional practice. In order to produce more plantain bananas seedlings, the vegetative multiplicative techniques like the micropropagation (tissue culture) and/or the macropropagation are required. The micropropagation technique allows rapid production of high quality, disease-free and true to type planting materials (vitro plants) within a short duration in limited space but the cost of production is however high for most of the developing countries [4]. However, the macropropagation technique of plants from stem bids (PIF) is an alternative to produces healthy and clean vivo plants [3].

PIF technique permits in a short period of time ( 2 to 3 months) at a low cost to generate quickly 20 to 100 plantain bananas seedlings from a single sucker depending on the variety and the technician's experience [3] [5]. However, PIF seedlings face the problems of acclimatization, contamination on farmlands and the position of the shoot on explants which influences the vigor of the plant [3] [6]. Indeed, this can lead to the loss of about $60 \%$ of the plants on farmlands (new plantation) and are sometimes rejected by some farmers.

The farmland milieu contains many pathogenic microorganisms which cause diseases on the plant amongst which Mycospharella fijiensis. It belongs to the 
ascomycetous fungi family of Mycospharella leaf spot disease which generates leaf disease, and black Sigatoka disease (BSD) being the more virulent one since it is more invasive in banana growing and severely reduces the foliar synthetic area on plants [7]. Therefore, economically and physiologically, the BSD is the most destructive disease of plantain bananas and accounts for losses of 50\% of bananas production [8]. Most cooking bananas and plantains (AAB and ABB) are moderately to highly resistant to black Sigatoka disease compared to bananas (AAA) generally highly susceptible [9]. In the nursery, the only control method for BSD is leaf removal (deleafing) [10], there is however a need to assess BSD effect on seedling in nursery.

Many chemical pesticides such as fungicides, bactericides, viricides, nematicides, insecticides ... are often used to destroy pathogenic agents but they however cause problems to humans and the environment. Indeed, these chemical constituents used in the agricultural methods to solve contamination problems on the field cause the pollution of soil and water and are very harmful for human health and the environment [11]. Moreover, the rapid emergence of fungicide resistance is conducive to a significant increase in the cost of disease control but, above all, to increasing negative environmental effects [12]. Unfortunately, these current tools of diseases management are not efficient and do not respect the ecosystem. Therefore, it is of both biological and agricultural importance to set up an integrated pest management (IPM) approach precisely for resistance to $M$. fijiensis in the nursery and the farm.

The less development of BSD was observed on susceptible Musa spp. cultivars when they were cultivated on sites rich in organic matter [13]. Furthermore, recent studies carried out in Ivory Coast have demonstrated that aqueous extract of $T$. diversifolia has a strong influence on rice protection and resistance against termites on farmland by acting as an insecticide in the control of rice cultivation [14] and by acting as a fertilizer and fungicide in the control of another culture [15]. Nowadays, the potential impact of $T$. diversifolia in agriculture as biofertilizer and biopesticide is receiving more attention. The main components of $T$. diversifolia called wild sunflower or tree marigold are minerals like nitrogen $(\mathrm{N})$, phosphorus $(\mathrm{P})$ and potassium $(\mathrm{K})$ averaging between (3\% - 5\%), (0.5\% - 2.5\%) and $(4 \%-6 \%)$ respectively and some secondary metabolites like Alkaloids (854 $\mathrm{mg}$ ), Flavonoids (339 mg) and Terpenoids (65 mg) [16] [17] [18]. Indeed, it is known as a non-fixing nitrogen plant and has the ability to enrich the surrounding soil with nutrients during decomposition [19].

Besides, a recent research has shown that soil amendment with Tithonia diversifolia alone or Tithonia diversifolia combine to clam shells protects efficiently the PIF seedlings leaves against the development of $M$. fijiensis, and also improves growth promotion [6]. The use of liquid extracts of Tithonia diversifolia in the production of PIF seedlings could be a new approach to improve the PIF performance. This study is aimed to evaluate the effect of liquid extracts of Tithonia diversifolia on the induced resistance of PIF plantain bananas seedlings 
against BSD. This work was conducted in Yaoundé, Cameroon from September 2016 to August 2017.

\section{Materials and Methods}

\subsection{Materials}

The study was carried out at the Biotechnology Center of the University of Yaoundé 1 in Cameroon ( $3^{\circ} 52^{\prime}$ North and $11^{\circ} 25^{\prime}$ East, 759 meters' altitude), located in the agroecological zone known as wet rainforest with Bimodal Rainfall.

Suckers of plantain (Musa spp., genome $\mathrm{AAB}$ ) were obtained from Lékié division (Obala) of the Centre region of Cameroon and were the variety of Big-Ebanga, selected due to their short cycle of production and their capacity to produce great number of PIF seedlings.

M. fijiensis strain was provided by African Centre for Research on Bananas and Plantain of Njombé in the Littoral region of Cameroon.

The substrates used in the greenhouse (white sawdust) and in the shade (sand and black soil, 2/3:1/3) were collected in the locality of Yaoundé, sterilized in an oven at different temperatures and time intervals as described by [3].

\subsection{Preparation of Extracts}

T. diversifolia was collected around the Biotechnology Center of the University of Yaoundé 1. The leaves were washed in running tap water, cut and then mixed with water in the ratio of 1:5 (w/v) before fermentation in recipients for 10 and 15 days according to the principle of the cold maceration that is at dry and cold conditions at room temperature. At the end of the fermentation period, each liquid extract obtained was used directly and then diluted $1 / 2$ in water to be used for explants and seedlings treatment while the ones treated with water served as control.

\subsection{Experimental Design}

This study was conducted under sterile condition and non-sterile (farmers) condition in the greenhouse and under shade following almost the same experimental design performed by [6], except for the treatments that were different.

The different treatments of the study were carried out in two completely randomized blocks with (05) treatments in each block in the greenhouse and in the shade.

$>$ Two blocks:

- Sterile Substrate (SS).

- Non-Sterile Substrate (NSS).

$>$ Five treatments (four liquid extracts of Tithonia diversifolia and one control):

- Control only water;

- A liquid extract-based of Tithonia diversifolia of 10 days (Extract 1);

- A diluted liquid extract-based of Tithonia diversifolia of 10 days (Extract 2);

- A liquid extract-based of Tithonia diversifolia of 15 days (Extract 3); 
- A diluted liquid extract-based of Tithonia diversifolia of 15 days (Extract 4). Each treatment in each block was considered as an Experimental Unit (EU). The PIF explants were prepared following the method used by [3]. In each EU, three (03) explants were introduced in the greenhouse. The seedlings germination and pre-emergence in the greenhouse was effective through explants watering with the different types of extracts.

\subsection{Assessment of Seedlings Vegetative Stages Growth Parameters}

The germination and pre-emergence parameter (cumulative number of seedling) was evaluation per EU after every seven days in the greenhouse for a period of five weeks.

After this period, the seedlings from the greenhouse were weaned in plastic planter bags at the stage of two or three small open leaves per seedling and for more than one root, then transferred under the shade following the same experimental design as in the greenhouse.

The effect of different liquid extract of Tithonia diversifolia on the vegetative growth stage were evaluated for each EU and three (03) seedlings were selected and labelled under the shade. The evaluation was done by measuring different agromorphological parameters:

- The height of the seedling;

- The diameter of the seedling pseudo-stems;

- The total foliar area of the seedling calculated with the formula reported by [3].

\section{TLS $=\mathrm{L} \times \mathrm{W} \times 0.8 \times$ number of leaves $\times 0.662\left(\mathrm{~cm}^{2}\right)$}

This evaluation was done every fourteen days starting from the day that the seedling entered the shade for acclimatization and was done for a period of six (06) successive weeks.

\subsection{Assessment of Seedlings Susceptibility to BSD}

A suspension of $M$. fijiensis strain concentrated at $10^{6}$ zoospores $/ \mathrm{mL}$ was prepared as [3] and applied through artificial inoculation on the leaves of PIF plantain bananas seedlings almost of the same age. Three (03) seedlings leaves per treatment aged of about 12-weeks were selected and labelled under the shade. Before inoculation, a leaf of each plant was detached and conserved at $-45^{\circ} \mathrm{C}$ in a plastic sachet for biochemical analysis of the before inoculation stage. An amount of $50 \mu \mathrm{L}$ droplet of inoculum suspension was then deposited midway through the exposed surface of the leaves. The symptoms were observed every two days, reported every four (04) days since the necrosis development on the treated leaves was very slow compared to the control. The necrotic surfaces area (NSA) was measured according to the method used by [3] [6]. After five weeks, a leaf of each plant was detached and conserved at $-45^{\circ} \mathrm{C}$ in a plastic sachet for biochemical analysis of biomarkers for the post-infection stage. 


\subsection{Assessment of Biomarker's Accumulation}

Biochemical analyses were carried out following the disease assessment on the whole leaves. The samples involved were cut at $1 \mathrm{~cm}$ beyond the necrotic point or beyond the marked scar (sections with no symptoms) and each treatment was repeated trice. The evaluation of the accumulation was done at the before inoculation and post-inoculation stages. For each treatment, $0.5 \mathrm{~g}$ of fresh leaf was used for the sample's analyses. The extraction and quantification of samples were carried out according to the method reported by [20]-[24] modified respectively for total phenolic $(760 \mathrm{~nm})$, total protein $(595 \mathrm{~nm})$, peroxidase $(470$ $\mathrm{nm})$, polyphenol oxidase $(330 \mathrm{~nm})$ and glucanase $(540 \mathrm{~nm})$. The total phenolics was measured in mg equivalent of gallic acid per $\mathrm{g}$ of fresh weight while that of the total proteins concentration was expressed in mg equivalent (Eq) of bovine serum albumin (BSA) per $\mathrm{g}$ of fresh weight (FW). The peroxidase and polyphenoloxidase concentration were expressed in $\mathrm{UE} / \mathrm{min} / \mathrm{g} \mathrm{FW}$, while the glucanase concentration was expressed in mg of glucose/g FW.

\subsection{Statistical Analyses}

The $T$. diversifolia liquid extracts effects on the PIF seedlings vegetative growth stages, the susceptibility to BSD and the biomarker's accumulation were analysed by subjection of the variables (the number of shoots, the height and the diameter of shoots, the foliar area, the necrotic surface, total proteins, total polyphenols, peroxidase, polyphenol oxidase and glucanase) to mixed three-way ANOVA performed with XLSTAT software. The length and weight of roots seedlings were analysed by subjection of both variables to mixed two-way ANOVA also performed with XLSTAT software. Each plant is being taken as experimental unit and condition or stage, treatment and day as factors. Multiple comparisons of the means were done by applying Tukey's test at 5\% probability level. Principal components analysis (PCA) with Pearson correlation between the different variables was also performed with XLSTAT software.

\section{Results}

\subsection{Effect of Seedlings Vegetative Stages Growth Parameters}

Liquid extracts of $T$. diversifolia (Extract 1, Extract 2, Extract 3 and Extract 4) were found to significantly $(P<0.0001)$ influence the vegetative stages growth parameters of PIF plantain bananas seedlings notably the number of shoots, the diameter and the height of shoots, the foliar area, the roots length and weight of roots compared to control (Table 1, Figure 1 and Figure 2). The coefficient of determination $\left(\mathrm{R}^{2}\right)$ for all these parameters was close to a $100 \%$ (Table 1) and showed thus that $T$. diversifolia model indicates a perfect fit. The most influential variable was the time for the number of shoots and foliar area, while it was the treatment for the diameter and the height of shoots, as well as the roots length and weight of roots. All these vegetative stages growth parameters evolve significantly in course of time. 


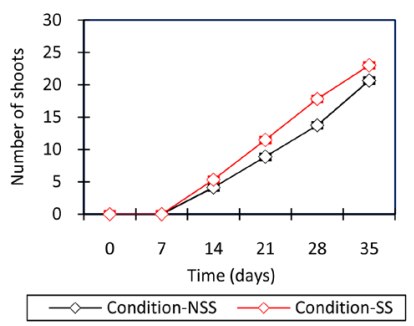

(a)

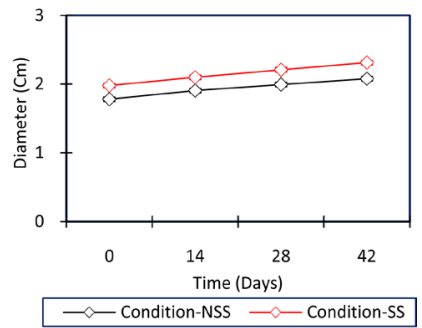

(c)

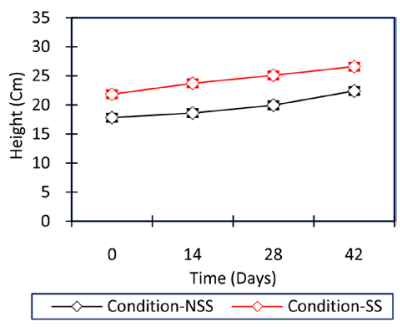

(e)

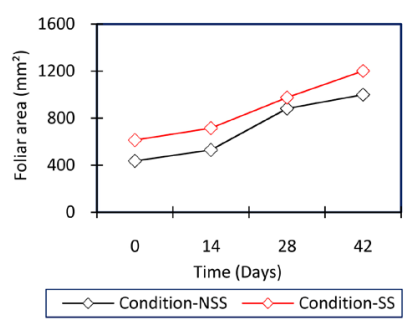

(g)

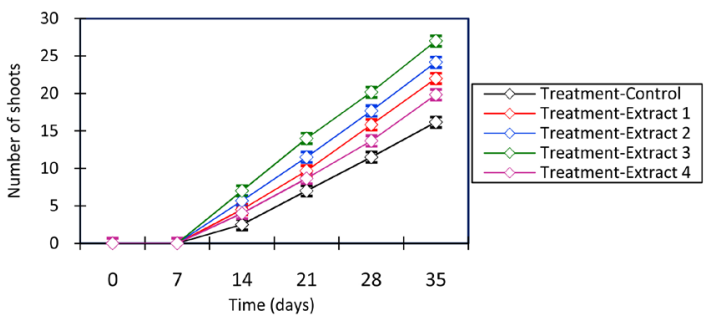

(b)

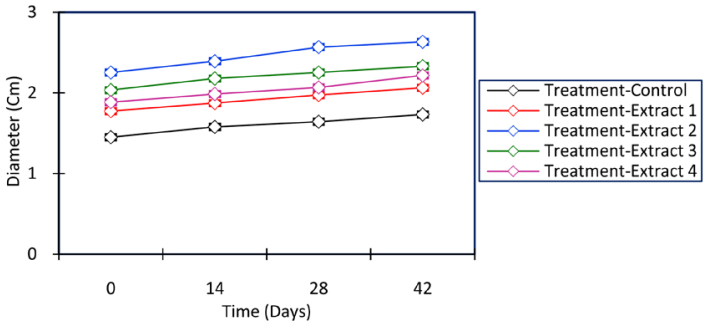

(d)

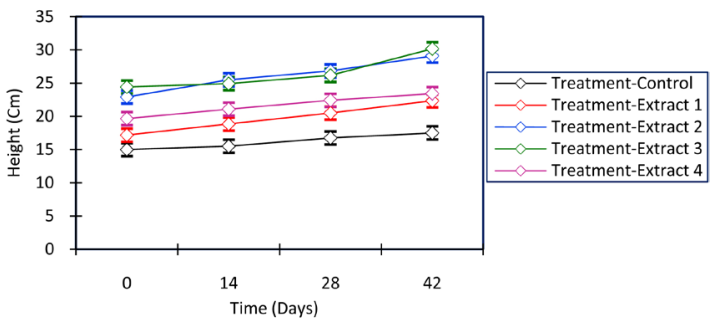

(f)

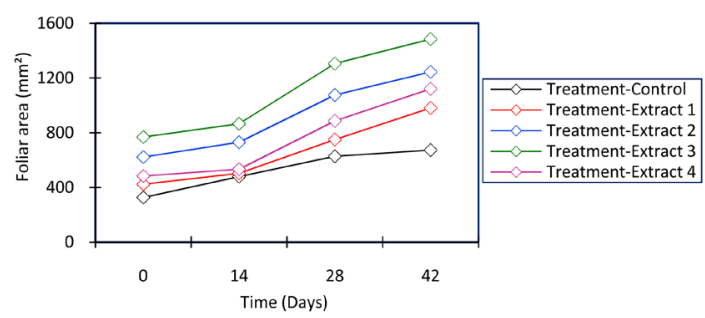

(h)

Figure 1. Effects of $T$. diversifolia liquid extracts in the greenhouse on the number of shoots, the diameter, height and foliar area of PIF plantain seedlings in course of time. Interaction plots of day and condition and of day and treatment respectively for the number of shoots ((a), (b)), the diameter ((c), (d)), the height ((e), (f)) and the foliar area $((\mathrm{g}),(\mathrm{h}))$. Each point represents the average mean of three replicates with the standard deviation for each treatment.

For the number of shoots, the diameter of shoots, the height of shoots and the foliar area, all the variables and the interactions were highly significant $(P<$ 0.0001) as shown in Table 1 except for the non-significant interactions of the diameter and the height of shoots (condition and time) and of the height of shoots (condition, treatment and time). The condition, the treatment and the interaction condition treatment were highly significant for the root's length and weight of roots. The treatment influences positively the roots development and the pre-emergence as shown in Figure 3. 
Table 1. Variance analysis of Extract based on Tithonia diversifolia effects on the PIF plantain seedlings agromorphological growth (number of shoots, diameter and height of shoots, foliar area, length and weight roots) and disease severity in the greenhouse and the shade. Values in bold correspond to tests where the null hypothesis is not accepted with a significance level alpha $=$ 0.05 . DF is the degree of freedom; $F$ is the value of $\mathrm{F}$ test and $P$ is the probability.

\begin{tabular}{|c|c|c|c|c|c|c|c|c|c|c|c|c|c|c|c|}
\hline \multirow[b]{3}{*}{ Source } & \multirow{2}{*}{\multicolumn{4}{|c|}{$\frac{\text { Number of shoots }}{\mathrm{R}^{2}=99 \%}$}} & \multirow{2}{*}{\multicolumn{2}{|c|}{$\begin{array}{c}\text { Diameter }(\mathrm{cm}) \\
\mathrm{R}^{2}=99 \%\end{array}$}} & \multirow{2}{*}{\multicolumn{2}{|c|}{$\begin{array}{c}\text { Height (cm) } \\
\mathrm{R}^{2}=96 \%\end{array}$}} & \multirow{2}{*}{\multicolumn{2}{|c|}{$\begin{array}{c}\text { Foliar area }\left(\mathrm{mm}^{2}\right) \\
\mathrm{R}^{2}=100 \%\end{array}$}} & \multirow{2}{*}{\multicolumn{3}{|c|}{$\begin{array}{c}\text { Roots length (cm) } \\
\mathrm{R}^{2}=99 \%\end{array}$}} & \multirow{2}{*}{\multicolumn{2}{|c|}{$\begin{array}{c}\text { Roots weight (g) } \\
\mathrm{R}^{2}=100 \%\end{array}$}} \\
\hline & & & & & & & & & & & & & & & \\
\hline & $\mathrm{DF}$ & F & $P$ & DF & F & $P$ & F & $P$ & $\mathrm{~F}$ & $P$ & DF & F & $P$ & $\mathrm{~F}$ & $P$ \\
\hline Condition & 1 & 173.400 & $<0.0001$ & 1 & 766.090 & $<0.0001$ & 436.580 & $<0.0001$ & $60,950.218$ & $<0.0001$ & 1 & 200.641 & $<0.0001$ & 7359.818 & $<0.0001$ \\
\hline Treatment & 4 & 187.722 & $<0.0001$ & 4 & 1429.833 & $<0.0001$ & 308.658 & $<0.0001$ & $91,072.287$ & $<0.0001$ & 4 & 481.893 & $<0.0001$ & 5766.474 & $<0.0001$ \\
\hline Time & 7 & 3133.382 & $<0.0001$ & 3 & 321.046 & $<0.0001$ & 81.409 & $<0.0001$ & $160,448.40$ & $<0.0001$ & 4 & - & $=$ & - & $=$ \\
\hline $\begin{array}{l}\text { Condition } \\
\text { Treatment }\end{array}$ & 4 & 2.752 & 0.031 & 4 & 123.465 & $<0.0001$ & 22.551 & $<0.0001$ & 8892.421 & $<0.0001$ & 4 & 9.714 & 0.000 & 485.210 & $<0.0001$ \\
\hline $\begin{array}{l}\text { Condition * } \\
\text { Time }\end{array}$ & 7 & 25.684 & $<0.0001$ & 3 & 1.614 & 0.193 & 1.857 & 0.144 & 1325.291 & $<0.0001$ & 3 & - & $=$ & - & $=$ \\
\hline $\begin{array}{c}\text { Treatment } \\
\text { Time }\end{array}$ & 28 & 24.238 & $<0.0001$ & 12 & 2.764 & 0.003 & 2.499 & 0.008 & 2872.525 & $<0.0001$ & 12 & $=$ & $=$ & $=$ & $=$ \\
\hline Condition * & & & & & & & & & & & & & & & \\
\hline $\begin{array}{l}\text { Treatment * } \\
\text { Time }\end{array}$ & 28 & 1.881 & 0.020 & 12 & 5.087 & $<0.0001$ & 1.327 & 0.220 & 553.150 & $<0.0001$ & 12 & - & $=$ & - & $=$ \\
\hline
\end{tabular}

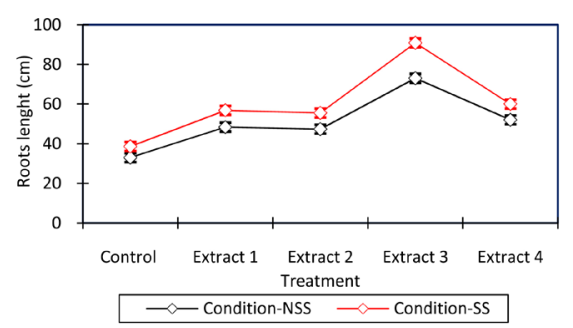

(a)

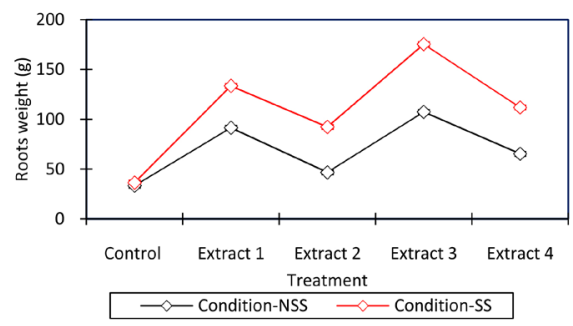

(b)

Figure 2. Effects of T. diversifolia liquid extracts on the root's length and weight of PIF plantain seedlings at the age of 16 weeks in course of time. Interaction plots of treatment and condition for the roots length (a), the roots weight (b). Each point represents the average mean of three replicates with the standard deviation for each treatment.

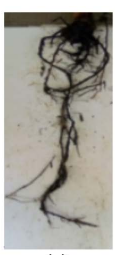

(a)

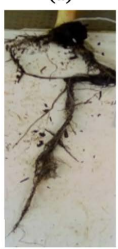

(f)

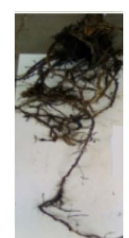

(b)

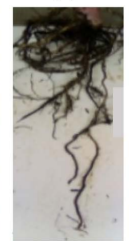

(g)

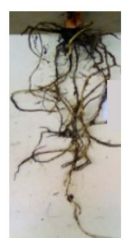

(c)

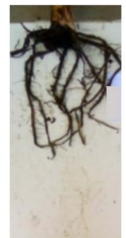

(h)

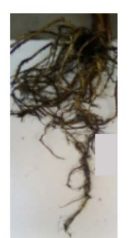

(d)

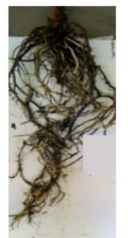

(i)

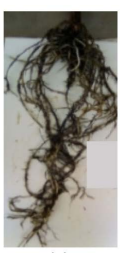

(e)

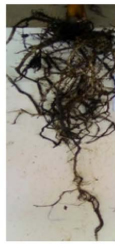

(j)

Figure 3. Effects of $T$. diversifolia liquid extracts on the roots of PIF plantain seedlings at the age of 16 weeks in sterilized substrate (SS) condition (up) and non-sterilized substrate (NSS) condition (down); from the left to the right (C) control and treatments E1, E2, E3 and $\mathrm{E} 4$ respectively. 
A significant difference was observed between the seedlings of the sterile substrate (SS) condition and non-sterile substrate (NSS) condition for all the vegetative stages growth parameters (the number of shoots, the diameter and the height of shoots, the foliar area, the roots length and weight of roots) and confirmed by the two statistically distinct groups obtained. These parameters were more important in the sterile substrate condition (SS) compared to the non-sterile substrate (NSS) condition, that is respectively 23 and 20 for the number of shoots 35 days after weaning (daw), 2.3 and $2 \mathrm{~cm}$ for the diameter of shoots 42 daw, 26.6 and $22.4 \mathrm{~cm}$ for the height of shoots 42 daw and 1201.73 and 999.69 $\mathrm{mm}^{2}$ for the foliar area 42 daw (Figure 1(a), Figure 1(c), Figure 1(e) and Figure $1(\mathrm{~g})$ ) and it was the same for the roots length and weight of roots (Figure 2(a) and Figure 2(b)). Despite the significant difference between the SS and NSS conditions, the $T$. diversifolia liquid extracts effect on the vegetative stages' growth was efficient in both conditions.

Regardless of the condition, the vegetative stages growth parameters (the number of shoots, the diameter and the height of shoots, the foliar surface, the roots length and the weight of roots) were consistently higher in the treated seedlings (Extract 1, 2, 3 and 4) compared to the control (untreated) ones as shown on Figure 1(b), Figure 1(d), Figure 1(f) and Figure 1(h) and Figure 2(a) and Figure 2(b). Therefore, distinct statistical groups were obtained to be precisely five groups (05) for the number of shoots, the diameter of shoots, the foliar surface and the weight of roots, and four (04) groups for the height of shoots and the roots length. The treatments that showed the best effect in terms of growth promotion at the germination and pre-emergence stage as well as at the vegetative stage is Extract 3 (Figure 1(b), Figure 1(d), Figure 1(f) and Figure 1 (h) and Figure 2).

\subsection{Effect of Seedlings Susceptibility to BSD}

Liquid extracts of $T$. diversifolia were found to significantly $(P<0.0001)$ influence the susceptibility to BSD of PIF plantain bananas seedlings (Table 2, Figure 4). The $\mathrm{R}^{2}$ value was equal to a $100 \%$ (Table 2) and the most influential variable was the treatment. The necrosis development evolves significantly and continuously in course of time. All the variables and the interactions were highly significant $(P<0.0001)$ for the BSD severity (Table 2$)$.

A significant difference was observed between the seedlings of the sterile substrate (SS) condition and non-sterile substrate (NSS) condition confirmed by the two distinct statistical groups obtained. The BSD severity was less important in the sterile substrate condition (SS) compared to the non-sterile substrate (NSS) condition (Figure 4(a)). Despite the significant difference between the SS and NSS conditions, the $T$. diversifolia liquid extracts effect on BSD severity was efficient in both conditions.

Regardless of the condition, the BSD severity was consistently lower in the treated seedlings (Extract 1, 2, 3 and 4) compared to the control (untreated) ones 
Table 2. Variance analysis of Extract based on Tithonia diversifolia effects on the PIF plantain seedlings biochemical markers accumulation (total proteins, total polyphenols, peroxidase, polyphenol oxidase and glucanase) at two stages (before inoculation and after inoculation). Values in bold correspond to tests where the null hypothesis is not accepted with a significance level alpha $=0.05$. DF is the degree of freedom; $F$ is the value of $\mathrm{F}$ test and $P$ is the probability.

\begin{tabular}{|c|c|c|c|c|c|c|c|c|c|c|c|c|c|c|}
\hline \multirow[b]{3}{*}{ Source } & \multicolumn{4}{|c|}{$\begin{array}{l}\text { Disease severity } \\
\quad\left(\mathrm{mm}^{2}\right)\end{array}$} & \multirow{2}{*}{\multicolumn{2}{|c|}{$\begin{array}{c}\begin{array}{c}\text { Total Phenolics } \\
\text { (mg Eq Cat/g FW) }\end{array} \\
\mathrm{R}^{2}=100 \%\end{array}$}} & \multirow{2}{*}{\multicolumn{2}{|c|}{$\begin{array}{c}\begin{array}{c}\text { Total Proteins } \\
\text { (mg Eq BSA/g FW) }\end{array} \\
\mathrm{R}^{2}=97 \%\end{array}$}} & \multirow{2}{*}{\multicolumn{2}{|c|}{$\begin{array}{c}\begin{array}{c}\text { Peroxidase } \\
(\mathrm{UE} / \mathrm{min} / \mathrm{g} \text { FW) }\end{array} \\
\mathrm{R}^{2}=97 \%\end{array}$}} & \multirow{2}{*}{\multicolumn{2}{|c|}{$\begin{array}{c}\text { Polyphenol oxidase } \\
\text { (UE/min/g FW) } \\
\qquad \mathrm{R}^{2}=93 \%\end{array}$}} & \multirow{2}{*}{\multicolumn{2}{|c|}{$\begin{array}{c}\begin{array}{c}\text { Glucanase } \\
\text { (mg of } \\
\text { glucose/g FW) }\end{array} \\
\mathrm{R}^{2}=89 \%\end{array}$}} \\
\hline & \multicolumn{4}{|c|}{$\mathrm{R}^{2}=100 \%$} & & & & & & & & & & \\
\hline & $\mathrm{DF}$ & $\mathrm{F}$ & $P$ & DF & $\mathrm{F}$ & $P$ & $\mathrm{~F}$ & $P$ & $\mathrm{~F}$ & $P$ & $\mathrm{~F}$ & $P$ & $\mathrm{~F}$ & $P$ \\
\hline Condition & 1 & 311.955 & $<0.0001$ & 1 & 3608.402 & $<0.0001$ & 7.449 & 0.009 & 8.193 & 0.006 & 51.816 & $<0.0001$ & 7.228 & 0.010 \\
\hline Treatment & 4 & $28,812.060$ & $<0.0001$ & 4 & 1689.244 & $<0.0001$ & 183.976 & $<0.0001$ & 135.858 & $<0.0001$ & 45.743 & $<0.0001$ & 18.282 & $<0.0001$ \\
\hline Stage & 6 & 8272.020 & $<0.0001$ & 1 & 2836.521 & $<0.0001$ & 628.578 & $<0.0001$ & 679.121 & $<0.0001$ & 252.101 & $<0.0001$ & 196.716 & $<0.0001$ \\
\hline $\begin{array}{l}\text { Condition }{ }^{*} \\
\text { Treatment }\end{array}$ & 4 & 58.958 & $<0.0001$ & 4 & 233.226 & $<0.0001$ & 34.732 & $<0.0001$ & 31.085 & $<0.0001$ & 5.079 & 0.002 & 10.235 & $<0.0001$ \\
\hline $\begin{array}{c}\text { Condition * } \\
\text { Stage }\end{array}$ & 6 & 21.987 & $<0.0001$ & 1 & 198.410 & $<0.0001$ & 40.879 & $<0.0001$ & 4.081 & 0.049 & 7.856 & 0.008 & 2.970 & 0.092 \\
\hline $\begin{array}{c}\text { Treatment } \\
\text { Stage }\end{array}$ & 24 & 2693.513 & $<0.0001$ & 4 & 112.794 & $<0.0001$ & 24.198 & $<0.0001$ & 16.232 & $<0.0001$ & 15.870 & $<0.0001$ & 9.052 & $<0.0001$ \\
\hline Condition * & & & & & & & & & & & & & & \\
\hline $\begin{array}{c}\text { Treatment } \\
\text { Stage }\end{array}$ & 24 & 22.516 & $<0.0001$ & 4 & 3608.402 & $<0.0001$ & 7.449 & 0.009 & 8.193 & 0.006 & 51.816 & $<0.0001$ & 7.228 & 0.010 \\
\hline
\end{tabular}

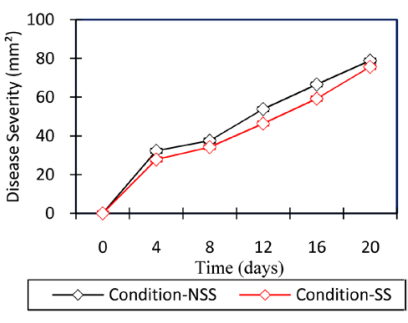

(a)

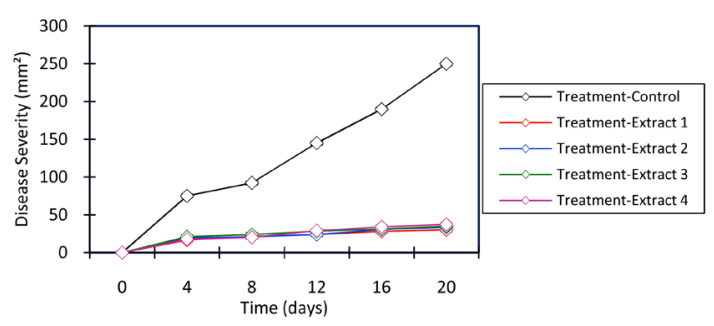

(b)

Figure 4. Effects of $T$. diversifolia liquid extracts in the shade on the necrotic surface of PIF plantain seedlings in course of time. Interaction plots of day and condition (a) and of day and treatment (b) for necrotic surface. Each point represents the average mean of three replicates with the standard deviation for each treatment.

(Figure 4(b)). The difference in terms of BSD severity was very significant between the treated (values between 30.17 and $37.42 \mathrm{~mm}^{2}$ ) and the untreated PIF seedlings $\left(250 \mathrm{~mm}^{2}\right)$ of plantain bananas (Figure 4 (b)). However, distinct statistical groups were obtained between the treated seedlings leading to five groups (05) for the BSD severity. T. diversifolia liquid extracts (Extracts 1, 2, 3 and 4) showed the best effect in terms of protection against BSD (Figure 4(b)).

\subsection{Effect of Biomarker's Accumulation}

Liquid extracts of $T$. diversifolia were found to significantly $(P<0.0001)$ influence the biomarkers accumulation parameters in the PIF plantain bananas seedlings notably the content of the total proteins, the total polyphenols and the defense-related enzyme (peroxidase, polyphenol oxidase and glucanase) compared to control (Table 2, Figure 5). The $\mathrm{R}^{2}$ value for all these parameters was 


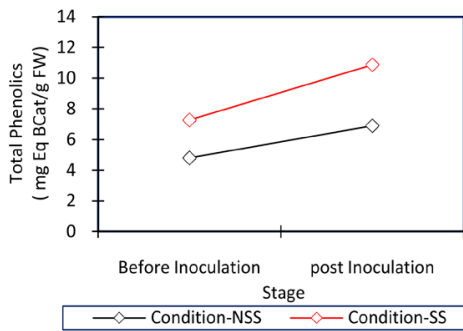

(a)

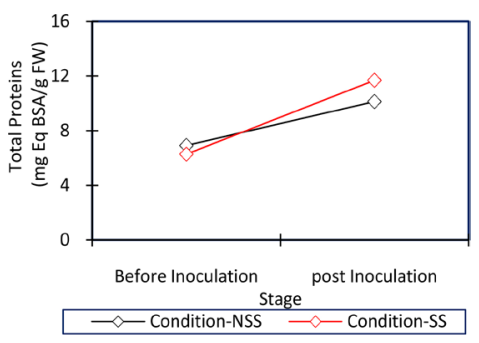

(c)

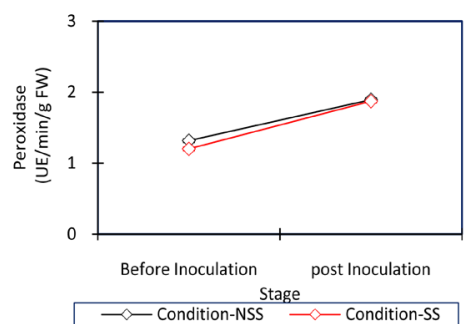

(e)

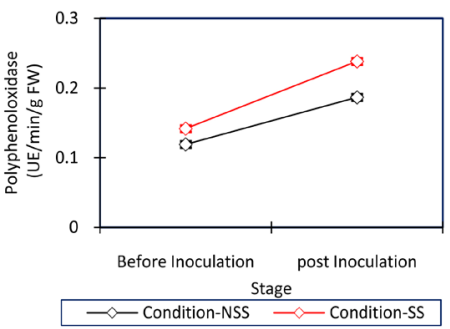

(g)

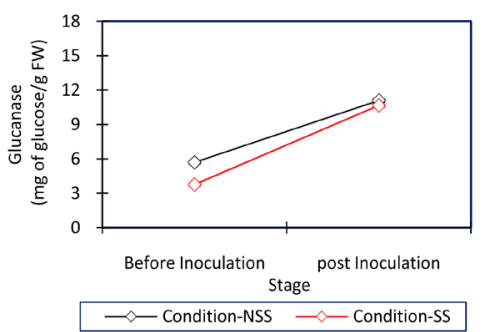

(i)

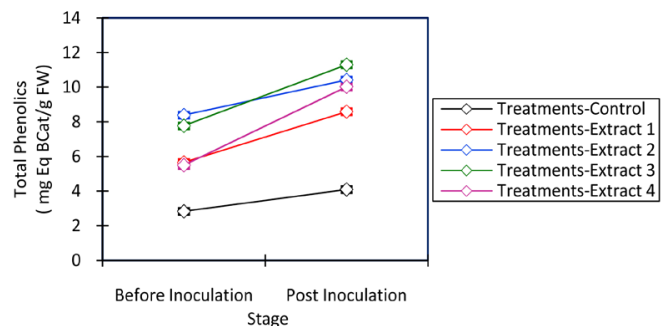

(b)

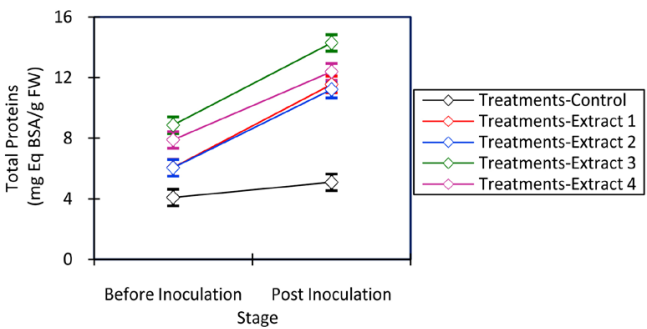

(d)

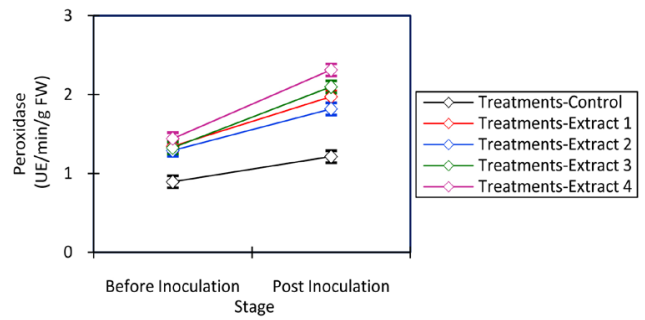

(f)

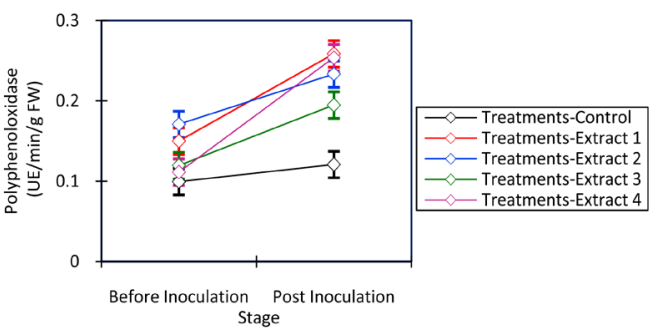

(h)

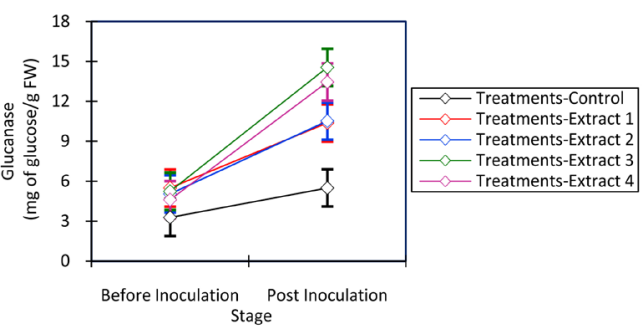

(j)

Figure 5. Effects of $T$. diversifolia liquid extracts on biochemical markers (total phenolics, total proteins, peroxidase, polyphenol oxidase and glucanase) accumulation before and after inoculation in the PIF plantain seedlings after treatment in the shade with $T$. diversifolia mulch. Interaction plots of stage and condition and of stage and treatment respectively for total phenolics ((a), (b)), total proteins ((c), (d)), peroxidase ((e), (f)), polyphenol oxidase ((g), (h)) and glucanase ((i), (j)). Each point represents the average mean of three replicates with the standard deviation for each treatment. 
close to a $100 \%$ (Table 2) and the most influential variable was the treatment for the total proteins, while it was the stage for total polyphenols, peroxidase, polyphenol oxidase and glucanase.

For the biomarker's accumulation parameters (the total proteins, the total polyphenols, the peroxidase, the polyphenol oxidase and the glucanase), most of the variables (condition, treatment and stage) and the interactions (condition and treatment, condition and stage, treatment and stage, condition, treatment and stage) were highly significant $(P<0.0001)$ as shown in Table 2 except for the non-significant interaction of the glucanase accumulation (condition and stage).

A significant difference was observed between the seedlings of the sterile substrate (SS) condition and non-sterile substrate (NSS) condition for all these biomarkers accumulation parameters and confirmed by the two distinct statistical groups obtained. These parameters were more important in the sterile substrate condition (SS) compared to the non-sterile substrate (NSS) condition, that is respectively (Figure 5(a), Figure 5(c), Figure 5(e), Figure 5(g) and Figure 5(i)). Despite the significant difference between the SS and NSS conditions, the T. diversifolia liquid extracts effect on the biomarker's accumulation was efficient in both conditions (Figure 6(a)). There was a significant difference between the stage before inoculation and the stage after inoculation for all these biomarkers and their amount increases importantly after inoculation (Figure 6(b)).

Regardless of the condition, these biomarkers accumulation parameters were consistently higher in the treated seedlings (Extract 1, 2, 3 and 4) compared to the control (untreated) ones as shown on Figure 5(b), Figure 5(d), Figure 5(f), Figure 5(h) and Figure 5(j). Therefore, distinct statistical groups were obtained to be precisely four groups (04) for the total proteins, the total polyphenols and the peroxidase, and three (03) groups for the polyphenol oxidase and the glucanase. The treatments that showed the best effect in terms of biomarkers accumulation is Extract 3 (Figure 6(c)).

\subsection{Principal Components Analysis (PCA)}

The variables involved in the growth promotion (the number of shoots, the diameter and the height of shoots, the foliar surface, the roots length and the weight of roots, the total proteins and the total phenolics) were well correlated to one another, and better correlation $(P>0.001)$ were encountered for vegetative growth variables (diameter and height of shoots, foliar surface, length and weight of roots).

These vegetative growth stage variables were well correlated to one another, but weakly correlated with the total phenolics, the total proteins and the enzyme's activity (peroxidase, polyphenol oxidase and glucanase). The number of shoots was weekly correlated to all the variables involved in the growth promotion as well as the biomarkers accumulation variables (Figure 7).

The variables involved in the seedling's protection against diseases notably BSD (disease severity, total proteins, total phenolics, peroxidase, polyphenol oxidase and glucanase) were well correlated $(P>0.001)$ to one another, except 


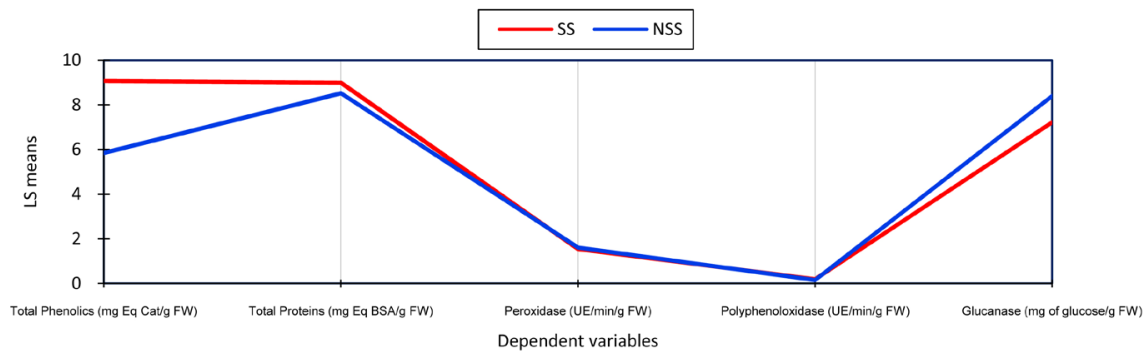

(a)

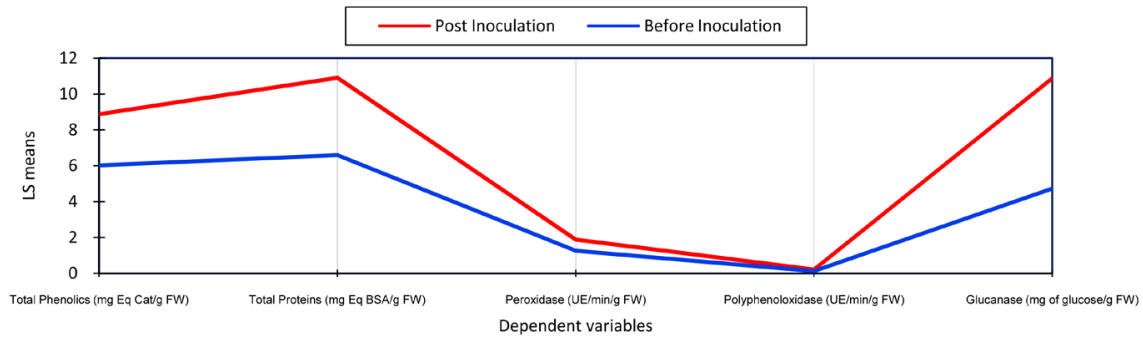

(b)

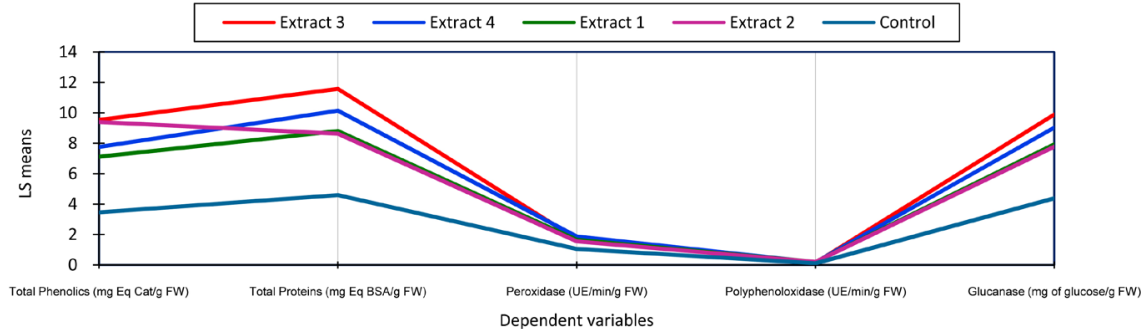

(c)

Figure 6. Least Squares (LS) means summary of biochemical markers (total phenolics, total proteins, peroxidase, polyphenol oxidase and glucanase) accumulation in the PIF plantain seedlings in the shade after $T$. diversifolia liquid extracts treatment before and after inoculation: Condition (a), Treatment (b) and stage (c). Letters A, B, C, D, E, F, G, $\mathrm{H}$, and I represent different statistical groups defined by the Tukey test (5\%).

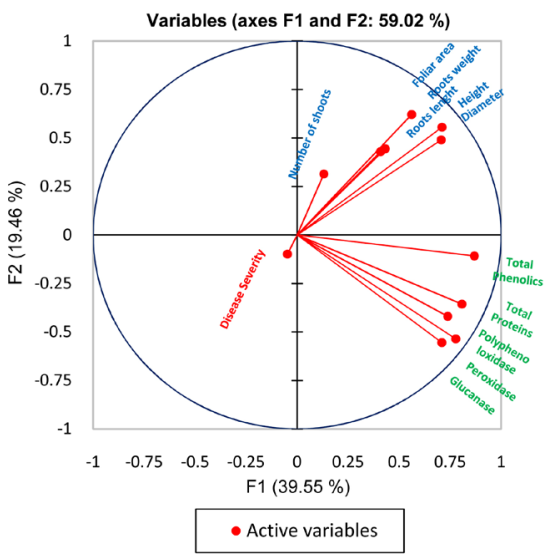

Figure 7. Principal components Analysis (PCA) of all the variables (number of shoots, diameter of shoots, height of shoots, foliar area, height and weight of shoots, necrotic surface of leaves, total proteins, total phenolics, peroxidase, polyphenol oxidase and glucanase). The PCA shows positive or negative correlation, but also the strength of the relationship between the variables. 
for the BSD severity that showed a very weak negative correlation $(P>0.05)$ with all the others variables (Figure 7).

\section{Discussion}

The liquid extracts of $T$. diversifolia influences significantly the BSD disease incidence with reduced level of susceptibility in the treated PIF plantain bananas seedlings. The antifungal and repulsive activity of fermented extract of $T$. diversifolia has been demonstrated as well as its effective antimicrobial properties against pests and disease phytopathogens [14] [20] [25] [26]. The less susceptibility of treated seedling could be due to an induced resistance established against $M$. fijiensis. Several studies have also reported that $T$. diversifolia contribute to plant protection by modifying the microbial community and stimulating plant defense mechanisms [14]. Under both conditions, liquid extracts of $T$. diversifolia were efficient defense inducer in PIF seedlings compared to the untreated ones. The results are in accordance with previous research on PIF seedlings and cocoa seedlings in nursery that have shown the effect of shells alone or clam shells combine with $T$. diversifolia on the induction of plant defense [3] [6] [27] [28]. However, the T. diversifolia liquid extracts protection level against BSD is high compared to those obtained by [3] [6], with the PIF substrate amendment.

This induction of systemic resistance by $T$. diversifolia liquid extracts could be due to its composition, but also the capacity of the extract to stimulate plant defense mechanisms and increase the synthesis of plant defense metabolites such as phenolic compounds and pathogen-related proteins and defense-related enzymes. Indeed, the classes of phenolic compounds, proteins as markers of resistance defense-related enzymes were strongly involved in the host/parasite interaction [29] [30] [31]. The efficacy of $T$. diversifolia liquid extracts have been shown through the induced resistance against BSD in the PIF plantain bananas seedlings, the high accumulation of total proteins and total phenolics, as well as the increase activity of peroxidase, polyphenol oxidase and glucanase before and after inoculation. The total phenols act either as a defensive or primary barrier inhibiting growth by promoting or activating the mobilization of $\beta$-1,3-glucans but as a second blocking barrier invasion by fungi while protecting host plant tissue from phytotoxic substances [30] [31]. The PR proteins are indispensable component of innate immune response in plants under biotic and abiotic stress conditions; they protect plants from further infection by not only accumulating locally in the infected and surrounds tissues, but also in remote uninfected tissues and are also involved in hypersensitive (HR) or systemic acquired resistance against infection [32]. The peroxidase and polyphenol oxidase are associated with reduction in the rate of pathogen multiplication and spread through the oxidation of substrates leading to the accumulation of toxic compounds as well as their catalytic role in the formation of lignin which is a molecule involved in the reinforcement of the plant cell wall [33] [34]. $\beta$-1,3-glucanase is strongly expressed following an abiotic and/or biotic stress, since it exhibits a fungicidal ac- 
tivity through the modification of the composition of the plant cell wall and involves in the destruction and destabilization of fungal wall structures [35] [36]. Our results are in line with previous studies that have clearly demonstrated that phenolics secondary metabolites play an important role in the defence mechanisms of Musa spp. [30] [37] [38]. The assessment of the early stage events post-inoculation in leaves treated with $T$. diversifolia liquid extracts could help to the elucidation of the interactions between the PIF seedling leaves and $M$. fijiensis.

The vegetative growth stages parameters evolve significantly in course of time and were significantly different between the treated seedlings and the untreated ones with a positive and clear treatment effect for Extract 3. The liquid extracts of $T$. diversifolia had the expected impact on PIF seedlings through an important growth promotion. This result is in line with formal findings which confirmed that aqueous extracts of $T$. diversifolia increased the germination percentage of maize [15], but also the germination and pre-emergence stage and vegetative growth stage of PIF plantain [3] [6] and of cocoa [27] [28] in nursery. The increase in the rate of germination and the vegetative growth stage of plantain bananas seedlings could be explained by nutrients release in the liquid extracts by T. diversifolia leaves such as nitrogen, phosphorus, potassium, magnesium well kwon for their physiological role in growth promotion and the improvement of soil properties [39] [40] as well as free secondary metabolites contained in the extracts and involved in physiological role of plant such as proteins and phenolic compounds (alcaoïds, Sesquiterpens, lactones and flavonoids) [41]. Beneficial effects of $T$. diversifolia liquid extracts start from the soil physicochemical and biological characteristic modification as microbiota which help plant roots to more and better assimilate uptakes [42]. This is in line with the roots pre-emergence and length development observed on the treated PIF plantain bananas seedlings suggesting a potential stimulatory role to $T$. diversifolia liquid extract that increases the assimilates availability during the growth and secondary metabolites accumulation.

\section{Conclusion}

The objective of this work was to evaluate the effect of liquid extracts of $T$. diversifolia on the susceptibility of PIF plantain bananas seedlings to black Sigatoka disease. Under both conditions of this assay, the liquid extract of $T$. diversifolia does not only improve the PIF seedlings susceptibility to BSD but also improves the vegetative growth stages of PIF plantain bananas seedlings, probably because it seems to acts as a biofungicide and a biofertilizer. Therefore, the liquid extracts of $T$. diversifolia could be acting as a vital stimulator improving the soil quality and the PIF seedlings vigor. It would be interesting to investigate the $T$. diversifolia liquid extracts microbiome, the bioactivity of these extracts as well as the biochemical and molecular mechanisms involved in plant defense and plant growth promotion. T. diversifolia liquid extracts could therefore be proposed to small holder farmers as a two in one solution for an eco-friendly agriculture in 
the nursery. Hence, this research could later be extended to the field level and to other pathosystems.

\section{Conflicts of Interest}

The authors declare no conflicts of interest regarding the publication of this paper.

\section{References}

[1] FAO (2018) Food and Agriculture Organization of the United Nations. FAO Statistics: Bananas. http://www.fao.org/faostat/en/\#data/QC

[2] IRAD/CARBAP (2012) Amélioration durable de la productivité et de la compétitive de la filière plantain au Cameroun par utilisation de technologies innovantes. Projet1: Plantain: $\mathrm{C} 2 \mathrm{D} /$ programme d'appui à la recherche agronomique.

[3] Ewané, C.A., Ndongo, F., Ngoula, K., Tene Tayo, P.M., Opiyo, S.O. and Boudjeko, T. (2019) Potential Biostimulant Effect of Clam Shells on Growth Promotion of Plantain PIF Seedlings (var. Big Ebanga \& Batard) and Relation to Black Sigatoka Disease Susceptibility. American Journal of Plant Science, 10, 1763-1788. https://doi.org/10.4236/ajps.2019.1010125

[4] George, P. and Manuel, J. (2013) Low Cost Tissue Culture Technology for the Regeneration of Some Economically Important Plants for Developing Countries. International Journal of Agriculture, Environment and Biotechnology, 6, 703-711.

[5] Kwa, M., Fonbah, C., Manga, G. and Bikoï, A. (2009) Performances des EFA à base de bananiers dans le grand sud du Cameroun: Quelques indicateurs techniques de leurs limites. Actes de l'atelier de clôture du REPARAC-Mbalmayo.

[6] Ewané, C.A., Milawé, C.A., Ndongo, E.F. and Boudjeko T. (2020) Influence of Clam Shells and Tithonia diversifolia Powder on Growth of Plantain PIF Seedlings (var. French) and Their Sensitivity to Mycosphaerella fijiensis. African Journal of Agricultural Research, 15, 393-411. https://doi.org/10.5897/AJAR2019.14486

[7] Ewané C.A., Chillet, M., Castelan, F., Brostaux, Y., Lassois, L., Ngando, E.J., Hubert, O., Chilin-Charles, Y., Lepoivre, P. and de Lapeyre de Bellaire, L. (2013) Impact of the Extension of Black Leaf Streak Disease on Banana Susceptibility to Post-Harvest Diseases. Fruits, 68, 351-365. https://doi.org/10.1051/fruits/2013081

[8] Onautshu, O.D. (2013) Caractérisation des populations de Mycosphaerella fijiensis et épidémiologie de la cercosporiose noire du bananier (Musa spp.) dans la région de Kisangani-République Démocratique du Congo. Thèse de doctorat ès science. Université Catholique de Louvain.

[9] Bennett, R.S. and Arneson, P.A. (2003) Black Sigatoka. The Plant Health Instructor. https://doi.org/10.1094/PHI-I-2003-0905-01

[10] Nfor, T.D., Ajong, F.D. and Nuincho, L.I. (2011) Evaluation of Varietal Response to Black Sigatoka Caused by Mycosphaerella fijiensis Morelet in Banana Nursery. International Research Journal of Plant Science, 2, 299-304.

[11] CNUCED (Conférence des Nations Unies sur le Commerce et le Développement) (2016) "Banane" un profil de produit de base par INFOCOMM; Fonds de la CNUCED pour l'information sur les marchés des produits de base agricoles.

[12] de Lapeyre de Bellaire, L., Fouré, E., Abadie, C. and Carlier, J. (2010) Black Leaf Streak Disease Is Challenging the Banana Industry. Fruits, 65, 327-342.

https://doi.org/10.1051/fruits/2010034 
[13] Oluma, H.O.A., Onekutu, A. and Onyezili, F.N. (2004) Reactions of Plantain and Banana Cultivars to Black Sigatoka Leaf Spot Disease in Three Farming Systems in the Nigerian Guinea Savanna. Journal of Plant Diseases and Protection, 111, 158-164. https://doi.org/10.1007/BF03356142

[14] Kaho, F., Yemefack, M., Feudjio-Teguefouet, P. and Tchantchouang, J.C. (2011) Effet combiné des feuilles de tithonya diversifolia et des engrais inorganiques sur les rendements du maïs et les propriétés d'un sol ferralitique au Centre Cameroun. Tropicultura, 29, 39-45.

[15] Kerebba, N., Oyedeji, A.O., Byamukama, R., Kuria, S.K. and Oyedeji, O.O. (2019) Pesticidal Activity of Tithonia diversifolia (Hemsl.) A. Gray and Tephrosia vogelii (Hook f.); Phytochemical Isolation and Characterization: A Review. South African Journal of Botany, 121, 366-376. https://doi.org/10.1016/j.sajb.2018.11.024

[16] Oyerinde, R.O., Otusanya, O.O. and Akpor, O.B. (2009) Allelopathic Effect of Tithonya diversifolia on the Germination, Growth and Cholorophyl of Maize (Zea mays L.). Scientific Research and Essay, 4, 879-888.

[17] Cobo, J.G., Barrios, E., Kaas, D.C.L. and Thomas, R.J. (2002) Nitrogen Mineralization and Crop Uptake from Surface-Applied Leaves of Green Manure Species on a Tropical Volcanic-Ash Soil. Biology and Fertility of Soils, 36, 87-92.

https://doi.org/10.1007/s00374-002-0496-y

[18] Diby, Y.K.S., Tahiri, Y.A., Akpesse, A.A.M., Trabi, C.S. and Kouassi, K.P. (2015) Evaluation de l'effet insecticide de l'extrait aqueux de Tithonia diversifolia (Hemsl.) gray (Asteracee) sur les termites en culture du riz (NERICA 1) au centre de la Cote d'Ivoire. Journal of Animal \& plant Sciences, 25, 3966-3976.

[19] Kandungu, J., Anjarwalla, P., Mwaura, L., Ofori, D.A., Jammadass, R., Stevenson, P.C. and Smith, P. (2013) "Pesticidal Plant Leaflet" Tithonya diversifolia (Hemsley) A. Gray. Kew Royal Botanic Gardens, World Agroforestry Centre.

[20] El Hadrami, A. (2000) Caractérisation de la résistance partielle des bananiers à la maladie des raies noires et évaluation de la variabilité de l'agressivité de l'agent causal Mycosphaerella fijiensis. Thèse présentée en vue de l'obtention d'un Doctorat d'Etat, Gembloux.

[21] Pirovani, P.C., Heliana, A.S.C., Regina, C.R., Dayane, S.G., Fatima, C.A. and Fabienne, M. (2008) Protein Extraction for Proteome Analysis from Cacao Leaves and Meristems, Organs Infected by Moniliophthora perniciosa, the Causal Agent for the Witches Broom Diseases. Electrophoresis Journal, 29, 2391-2401. https://doi.org/10.1002/elps.200700743

[22] Boudjeko, T., Omokolo, N.D., Driouich, A. and Balangé, A.P. (2005) Peroxidase and Pectin Methylesterase Activities in Cocoyam (Xanthosoma sagittifolium L. Schott) Roots upon Pythium myriotylum Inoculation. Journal of Phytopathology, 153, 409-416. https://doi.org/10.1111/j.1439-0434.2005.00993.x

[23] Van Kammenn, A. and Broumer, D. (1964) Increase of Polyphenoloxidase Activity by a Local Virus Infection in Uninoculated Parts of Leaves. Virology, 22, 9-14. https://doi.org/10.1016/0042-6822(64)90042-X

[24] Leelasuphakul, W., Sivanunsakul, P. and Phongpaichit, S. (2006) Purification, Characterization and Synergistic Activity of $\beta$-1,3-Glucanase and Antibiotic Extract from an Antagonistic Bacillus Subtilis NSRS 89-24 against Rice Blast and Sheath Blight. Enzyme and Microbial Technology, 38, 990-999. https://doi.org/10.1016/j.enzmictec.2005.08.030

[25] Gray, H.A. (2005) Allelopathic Effects of Mexican Sunflower Tithonia diversifolia on Germination and Growth of Spider Plant (Cleome Gynandra L.) Journal of Bio- 
diversity and Environmental Sciences, 2, 26-35.

[26] Umar, O.B., Alex, R.D. and Obukohwo, E.E. (2015) Phytochemical and Proximate Composition of Tithonia diversifolia (Hemsl.) A. Gray. Annals Food Science and Technology, 16, 195-200.

[27] Téné Tayo, P.M., Ewané, C.A., Effa, O.P. and Boudjeko, T. (2017) Effet du chitosane et des coquilles d'huître sur la croissance des plants de cacaoyers et la résistance vis-à-vis phytophthora megakara agent responsable de la pourriture brune des cabosses de cacao. African Journal of Plant Science, 11, 331-340.

[28] Téné Tayo, P.M., Dzelamonyuy, A., Omokolo, N.D. and Boudjeko, T. (2019) Enhancement of Theobroma cacao Seedling Growth and Tolerance to Phytophthora megakarya by Heat-Treated Oyster Shell Powder. American Journal of Plant Sciences, 10, 578-594. https://doi.org/10.4236/ajps.2019.104042

[29] Ewané C.A., Lepoivre P., de Lapeyre de Bellaire, L. and Lassois, L. (2012) Involvement of Phenolic Compounds in the Susceptibility of Bananas to Crown Rot. Biotechnolgy Agronomy Society and Environmental, 16, 393-404.

[30] Dhakshinamoorthy, S., Mariama, K., Elsen, A. and De Waele, D. (2014) Phenols and Lignin Are Involved in the Defence Response of Banana (Musa) Plants to Radopholus similis Infection. Nematology, 16, 565-576.

https://doi.org/10.1163/15685411-00002788

[31] de Ascensao, A.R.F.D.C. and Dubery, I.A. (2003) Soluble and Wall-Bound Phenolics and Phenolic Polymers in Musa acuminata Roots Exposed to Elicitors from $\mathrm{Fu}$ sarium oxysporum f.sp. Cubense. Phytochemistry, 63, 679-686. https://doi.org/10.1016/S0031-9422(03)00286-3

[32] Jain, D. and Khurana, J.P. (2018) Role of Pathogenesis-Related (PR) Proteins in Plant Defense Mechanism. In: Singh, A. and Singh, I., Eds., Molecular Aspects of Plant-Pathogen Interaction, Springer, Singapore. https://doi.org/10.1007/978-981-10-7371-7_12

[33] Passardi, F., Cosio, C., Penel, C. and Dunand, C. (2005) Peroxidases Have More Functions than a Swiss Army Knife. Plant Cell Reports, 24, 255-265. https://doi.org/10.1007/s00299-005-0972-6

[34] Mayer, A.M. and Harel, E. (1979) Polyphenol Oxidases in Plants. Phytochemistry, 18, 193-215. https://doi.org/10.1016/0031-9422(79)80057-6

[35] Thakker, J.N., Patel, S. and Dhandhukia, P.C. (2013) Induction of Defense-Related Enzymes in Banana Plants: Effect of Live and Dead Pathogenic Strain of Fusarium oxysporum f. sp. cubense. ISRN Biotechnology. https://doi.org/10.5402/2013/601303

[36] Liu, B., Lu, Y. and Xing Zhang, Z. (2009) Identification and Antifungal Assay of a Wheat $\beta$-1,3-Glucanase. Biotechnology Letters, 31, 1005-1010. https://doi.org/10.1007/s10529-009-9958-8

[37] Collingborn, F.M.B., Gowen, S.R. and Mueller-Harvey, I. (2000) Investigations into the Biochemical Basis for Nematode Resistance in Roots of Three Musa Cultivars in Response to Radopholus similis Infection. Journal of Agricultural and Food Chemistry, 48, 5297-301. https://doi.org/10.1021/jf000492z

[38] Wuyts, N., Lognay, G., Verscheure, M., Marlier, M., De Waele, D. and Swennen, R. (2007) Potential Physical and Chemical Barriers to Infection by the Burrowing Nematode Radopholus similis in Roots of Susceptible and Resistant Banana (Musa spp.). Plant Pathology, 56, 878-890.

https://doi.org/10.1111/j.1365-3059.2007.01607.x

[39] Purbajanti, E.D., Slamet, W., Fuskhah, E. and Rosyida (2019) Effects of Organic and 
Inorganic Fertilizers on Growth, Activity of Nitrate Reductase and Chlorophyll Contents of Peanuts (Arachis hypogaea L.) IOP Conference Series Earth and Environmental Science, 250, Article ID: 012048.

https://doi.org/10.1088/1755-1315/250/1/012048

[40] Kulcheski, F.R., Côrrea, R., Gomes, I.A., de Lima, J.C. and Margis, R. (2015) NPK Macronutrients and microRNA Homeostasis. Frontiers in Plant Science, 6, 451. https://doi.org/10.3389/fpls.2015.00451

[41] Sharma, A., Shahzad, B., Rehman, A., Bhardwaj, R., Landi, M. and Zheng, B. (2019) Response of Phenylpropanoid Pathway and the Role of Polyphenols in Plants under Abiotic Stress. Molecules, 24, 2452. https://doi.org/10.3390/molecules24132452

[42] Yuncai, B., Hucs, Z. and Schmidhalt, U. (2008) Effect of Foliar Fertilization Application on the Growth and Mineral Nutrient content of Maize Seedling under Drought and Salinity. Journal of Botany, 5, 1747-1765. 